\title{
Influence of $\mathrm{OH}^{-}$Ion Concentration on the Surface Morphology

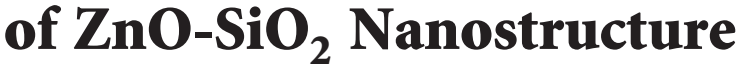

\author{
Jessica Ven G. Tinio, Key T. Simfroso, Amber Dea Marie V. Peguit, \\ and Rolando T. Candidato Jr. \\ Materials Science Laboratory, Physics Department, College of Science and Mathematics, \\ Mindanao State University-Iligan Institute of Technology, A. Bonifacio Avenue, Tibanga, 9200 Iligan, Philippines
}

Correspondence should be addressed to Rolando T. Candidato Jr.; r.candidatojr@gmail.com

Received 23 July 2015; Revised 2 September 2015; Accepted 3 September 2015

Academic Editor: Yuxin Zhao

Copyright ( 2015 Jessica Ven G. Tinio et al. This is an open access article distributed under the Creative Commons Attribution License, which permits unrestricted use, distribution, and reproduction in any medium, provided the original work is properly cited.

\begin{abstract}
The influence of varying $\mathrm{OH}^{-}$ion concentration on the surface morphology of chemically deposited $\mathrm{ZnO}-\mathrm{SiO}_{2}$ nanostructures on glass substrate was investigated. The morphological features, phase structure, and infrared characteristics were examined by scanning electron microscopy (SEM), X-ray diffraction (XRD), and Fourier transform infrared spectroscopy (FTIR), respectively. Results revealed that silica significantly changes the hexagonal morphology of bare $\mathrm{ZnO}$ rod to "pointed tips" when using low initial $\mathrm{OH}^{-}$precursor concentration. Increasing $\mathrm{OH}^{-}$ion concentration resulted in a "flower-like" formation of $\mathrm{ZnO}_{-} \mathrm{SiO}_{2}$ and a remarkable change from "pointed tips" to "hemispherical tips" at the top surface of the rods. The surface capping of $\mathrm{SiO}_{2}$ to $\mathrm{ZnO}$ leads to the formation of these "hemispherical tips." The infrared spectroscopic analysis showed the characteristics peaks of $\mathrm{ZnO}$ and $\mathrm{SiO}_{2}$ as well as the $\mathrm{Si}-\mathrm{O}-\mathrm{Zn}$ band which confirms the formation of $\mathrm{ZnO}-\mathrm{SiO}_{2}$. Phase analysis manifested that the formed $\mathrm{ZnO}-\mathrm{SiO}_{2}$ is of wurtzite structure. Furthermore, a possible growth mechanism is proposed based on the obtained results.
\end{abstract}

\section{Introduction}

Zinc oxide $(\mathrm{ZnO})$ is a widely known $n$-type semiconductor that attracted research interest due to its properties like wide energy band gap of $3.37 \mathrm{eV}$ and high exciton binding energy of $60 \mathrm{meV}$ [1] which makes it suitable for many applications like in solar cells [2], photodetectors [3], and gas sensors [4]. Another interesting aspect of $\mathrm{ZnO}$ growth is its ability to be engineered to different structural features by changing some parameters during synthesis. Tailoring the morphology, shape, and size of $\mathrm{ZnO}$ could be a way of expanding its potential especially in solar cell and sensor technologies where reaction at the surface is very crucial. Works have been reported for controlling size and shape of $\mathrm{ZnO}$ nanostructures like varying the initial zinc and hydroxyl ion concentrations $[5,6]$ and also by introducing silica $\left(\mathrm{SiO}_{2}\right)$ to $\mathrm{ZnO}$ as a concept of composite material $[7,8]$. With good mechanical resistance and high dielectric strength, $\mathrm{SiO}_{2}$ is likely to be an ideal component to enhance the properties of $\mathrm{ZnO}$. $\mathrm{ZnO}-\mathrm{SiO}_{2}$ is seen to have significant potential application as an antibacterial coating [9], luminescent material [10,11], photocatalyst [12], and also as gas sensor [13] because of the good sensing capability of $\mathrm{ZnO}$ which could be enhanced more with the presence of $\mathrm{SiO}_{2}$ for size and shape control that could lead to better chemical activity at the surface. However, understanding the mechanism for the growth of $\mathrm{ZnO}-\mathrm{SiO}_{2}$ nanostructures is still a formidable task particularly on controlling its surface morphology. Aside from these, most works related to $\mathrm{ZnO}$ synthesis use complex processes and sophisticated equipment like PLD [14], CVD $[15,16]$, and vapor phase transport process [17-19] among others which is not practical and economical in nature.

Recently, we reported preliminary investigations on the synthesis of $\mathrm{ZnO}-\mathrm{SiO}_{2}$ both in powder form [20] and deposited on glass substrates [21] by using simple wet chemical deposition process. It is also worth mentioning that the $\mathrm{SiO}_{2}$ from rice husk ash, a naturally occurring material, was used as an alternative to the expensive liquid tetraethyl orthosilicate (TEOS). We found out that $\mathrm{SiO}_{2}$ modifies the surface of $\mathrm{ZnO}$ from hexagonal into pointed tips 
TABLE 1: List of parameters of solution used for $\mathrm{ZnO}-\mathrm{SiO}_{2}$ synthesis.

\begin{tabular}{lccc}
\hline Sample & $\mathrm{ZnSO}_{4}$ concentration & $\mathrm{NH}_{4} \mathrm{OH}$ concentration & $\mathrm{SiO}_{2}$ \\
\hline 1 & $0.03 \mathrm{M}$ & $1.0 \mathrm{M}$ & 0.1 grams \\
2 & $0.03 \mathrm{M}$ & $2.0 \mathrm{M}$ & 0.1 grams \\
3 & $0.03 \mathrm{M}$ & $3.0 \mathrm{M}$ & 0.1 grams \\
\hline
\end{tabular}

and confirms the attachment of $\mathrm{SiO}_{2}$ to $\mathrm{ZnO}$ through FTIR spectroscopy. In this current contribution, the influence of initial $\mathrm{OH}^{-}$ion concentration on the surface morphology of $\mathrm{ZnO}-\mathrm{SiO}_{2}$ is presented. Moreover, a proposed mechanism for the growth of $\mathrm{ZnO}-\mathrm{SiO}_{2}$ on glass substrates is also presented based on the evolution of morphology of $\mathrm{ZnO}-\mathrm{SiO}_{2}$ with varying initial $\mathrm{OH}^{-}$ion concentration. Results of this work would pave the way for the control of the morphology of the nanostructures and for its possible use as methane gas detector.

\section{Experimental Procedure}

2.1. Wet Chemical Deposition Process. $\mathrm{ZnO}-\mathrm{SiO}_{2}$ nanostructures were synthesized through low temperature chemical deposition process using zinc sulphate $\left(\mathrm{ZnSO}_{4}\right)$ and ammonium hydroxide $\left(\mathrm{NH}_{4} \mathrm{OH}\right)$. First, $0.03 \mathrm{M} \mathrm{ZnSO}_{4}$ aqueous solution and varied ammonium hydroxide $\left(\mathrm{NH}_{4} \mathrm{OH}\right)$ concentrations $(1.0 \mathrm{M}, 2.0 \mathrm{M}$, and $3.0 \mathrm{M})$ were prepared separately in a beaker. The ammonium hydroxide was then added dropwise to the $\mathrm{ZnSO}_{4}$ solution and magnetically stirred while subsequently placing the precleaned glass substrates. After 30 minutes' stirring of the mixed precursors, 0.1 grams of laboratory (in-house) prepared amorphous silica powder was then added and then the solution was continuously stirred for 3 hours while maintaining the bath temperature at $70^{\circ} \mathrm{C}$. After 3 hours of constant stirring and heating, the substrates were washed with distilled water in order to remove loosely attached residues present and were allowed to dry at ambient room temperature. Table 1 shows the parameters considered for the synthesis of $\mathrm{ZnO}-\mathrm{SiO}_{2}$ where fixed concentration of $\mathrm{ZnSO}_{4}$ was used at varying $\mathrm{NH}_{4} \mathrm{OH}$ concentrations. The amount of amorphous silica powder used was the same for all samples.

2.2. Characterization of Materials. The morphological characteristics of the samples were studied using JEOL JSM6510LA analytical scanning electron microscope at low and high magnifications. Functional groups were determined by using Perkin Elmer Spectrum 100 infrared spectrometer from 4000 to $650 \mathrm{~cm}^{-1}$ over 32 scans with $4 \mathrm{~cm}^{-1}$ spectral resolution. Phase analysis of the samples was studied by X-ray diffraction analysis using Shimadzu XRD-7000 diffractometer from 5 to $40^{\circ}(2 \theta)$ with step scanning mode of $0.02^{\circ}(2 \theta)$.

\section{Chemistry of Precursors for the Synthesis of ${\mathrm{ZnO}-\mathrm{SiO}_{2}}$}

To understand the mechanism for the deposition of $\mathrm{ZnO}$ $\mathrm{SiO}_{2}$, it is better to look first on the growth of $\mathrm{ZnO}$ prior to addition of $\mathrm{SiO}_{2}$. The reaction between zinc sulfate and ammonium hydroxide upon dissociation in aqueous solution results in the formation of $\mathrm{Zn}(\mathrm{OH})_{2}$ which acts as seed nuclei for the growth of $\mathrm{ZnO}$. The reaction is expressed in

$$
\mathrm{ZnSO}_{4}+2 \mathrm{NH}_{4} \mathrm{OH} \longrightarrow \mathrm{Zn}(\mathrm{OH})_{2}+\left(\mathrm{NH}_{4}\right)_{2}(\mathrm{SO})_{4}
$$

The formation of $\mathrm{Zn}(\mathrm{OH})_{2}$ induces rapid nucleation and further addition of ammonia dissolves the solid $\mathrm{Zn}(\mathrm{OH})_{2}$ to form ammonium-zincate bath shown in

$$
\begin{aligned}
& \mathrm{Zn}(\mathrm{OH})_{2(\mathrm{~s})}+4 \mathrm{NH}_{4} \mathrm{OH}_{(\mathrm{aq})} \\
& \quad \longrightarrow\left(\mathrm{NH}_{4}\right)_{2} \mathrm{ZnO}_{2(\mathrm{aq})}+2 \mathrm{H}_{2} \mathrm{O}_{(\mathrm{aq})}
\end{aligned}
$$

On further reaction with water in the active solution during deposition, $\mathrm{ZnO}$ forms according to this chemical reaction:

$$
\left(\mathrm{NH}_{4}\right)_{2} \mathrm{ZnO}_{2(\mathrm{~s})}+\mathrm{H}_{2} \mathrm{O}_{(\mathrm{aq})} \longrightarrow \mathrm{ZnO}_{(\mathrm{s})}+\mathrm{NH}_{4} \mathrm{OH}_{(\mathrm{aq})}
$$

Upon addition of $\mathrm{SiO}_{2}$ to the solution, the silica particles in the solution might interact with the $\mathrm{OH}^{-}$group of $\mathrm{Zn}(\mathrm{OH})_{2}$ because the surface of silica is composed of functional groups, namely, siloxane ( $\mathrm{Si}-\mathrm{O}-\mathrm{Si}$ ) bridges and silanol groups ( $\mathrm{Si}$ $\mathrm{OH}$ ) where the $\mathrm{OH}^{-}$group acts as the center of molecular adsorption. Thus, a competition of attraction to $\mathrm{OH}$-group of the $\mathrm{Zn}(\mathrm{OH})_{2}$ seed nuclei between silica and the formation of $\mathrm{ZnO}$ is possible to happen.

\section{Results and Discussions}

4.1. Characteristics of $\mathrm{ZnO}-\mathrm{SiO}_{2}$ Using $1.0 \mathrm{M} \mathrm{NH}_{4} \mathrm{OH}$. To show that indeed $\mathrm{ZnO}-\mathrm{SiO}_{2}$ can be synthesized using silica from rice husk ash via chemical deposition process, a figure of bare $\mathrm{ZnO}$ is presented first to have an idea on what would be the effect of $\mathrm{SiO}_{2}$ on $\mathrm{ZnO}$. Figure 1(a) presents a typical micrograph of $\mathrm{ZnO}$ grown on glass substrate. It was observed that dense and well-defined hexagonal nanorods were present and preferentially grow perpendicular to the glass substrate, though some were tilted. The hexagonal feature of the micrograph is a characteristic of a wurtzite structure which is the more stable phase of synthetic $\mathrm{ZnO}$. Figure 1(b) meanwhile shows the corresponding IR spectra of bare $\mathrm{ZnO}$. The peaks observed at $779 \mathrm{~cm}^{-1}$ and $3279 \mathrm{~cm}^{-1}$ are attributed to the stretching mode and hydroxyl group of $\mathrm{ZnO}$, respectively [22]. On the other hand, Figure 2 shows the micrograph of amorphous $\mathrm{SiO}_{2}$ and its FTIR data. It can be seen in Figure 2(a) that the $\mathrm{SiO}_{2}$ particles were agglomerated and were found to have micron size $(>3 \mu \mathrm{m})$. Additionally, Figure 2(b) presents the characteristic infrared spectra of amorphous $\mathrm{SiO}_{2}$. Peak observed at $474 \mathrm{~cm}^{-1}$ is for the bending vibration of Si-O-Si bond while 804 and $1098 \mathrm{~cm}^{-1}$ are the vibrational bonds of Si-O. The peak at $3470 \mathrm{~cm}^{-1}$ is for both the $\mathrm{Si}-\mathrm{OH}$ and the $\mathrm{O}-\mathrm{H}$ vibration of physically adsorbed water [23].

Figure 3 on the other hand shows the micrographs using the same concentration of precursors as in Figure 1 but added with amorphous $\mathrm{SiO}_{2}$ powder grown also on glass substrates. It can be observed that the micrographs have uniform growth of dense $\mathrm{ZnO}$ rods. The surface morphology 


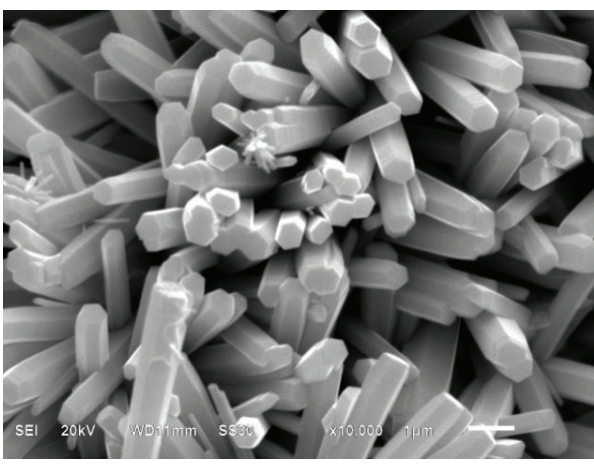

(a)

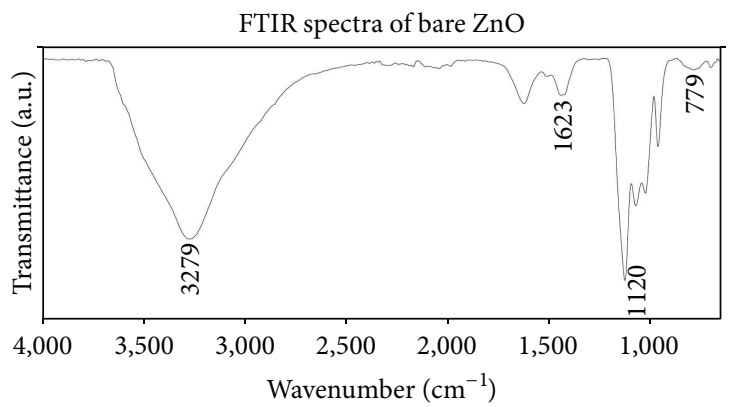

(b)

Figure 1: (a) SEM image of as-grown bare $\mathrm{ZnO}$ on glass substrate using $0.03 \mathrm{M} \mathrm{ZnSO}_{4}$ and $1.0 \mathrm{M} \mathrm{NH}_{4} \mathrm{OH}$ showing hexagonal rods and (b) corresponding FTIR spectra.

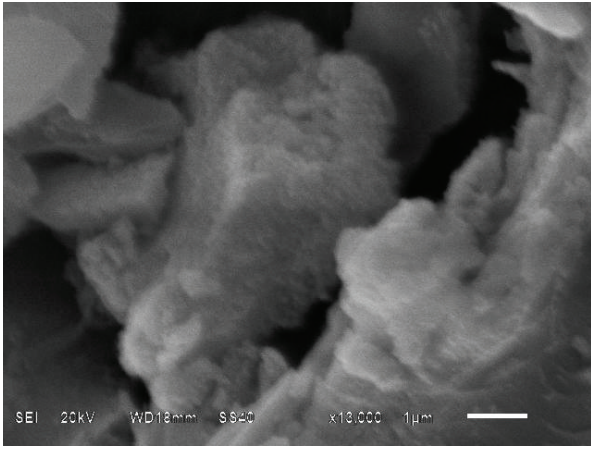

(a)

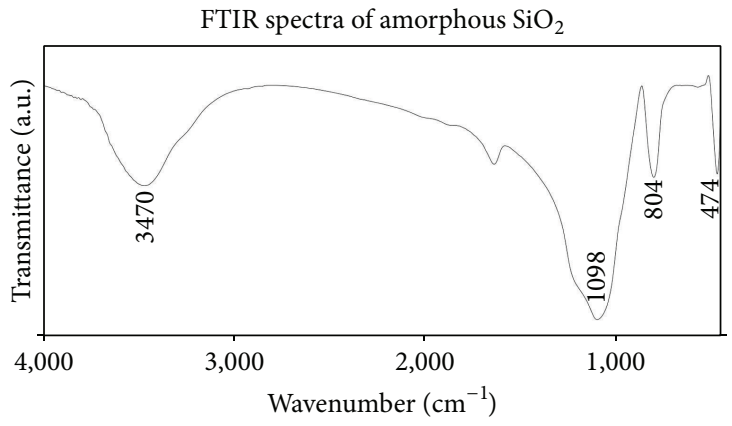

(b)

FIGURE 2: (a) SEM image of amorphous silica and (b) its corresponding FTIR spectra peaks.

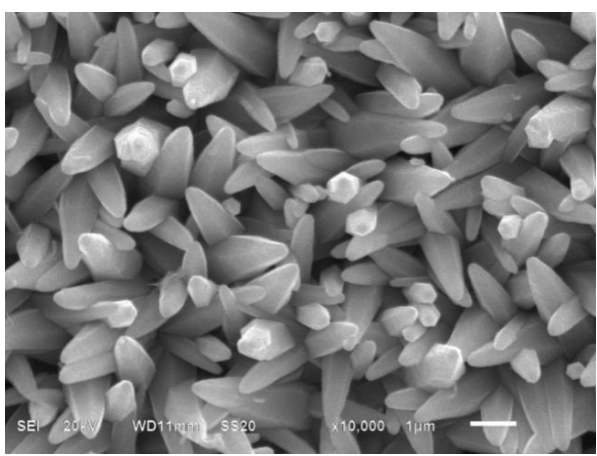

(a)

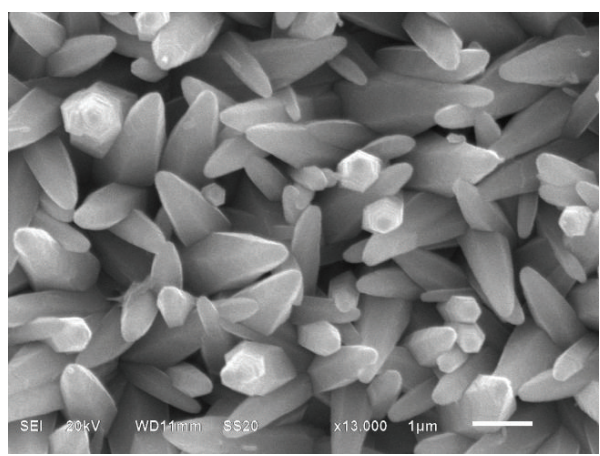

(b)

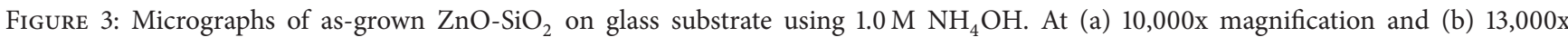
magnification.

shows the preferential growth at $c$-axis having pointed tips of approximately $250 \mathrm{~nm}$ in average diameter and $2 \mu \mathrm{m}$ in average length which is far different compared to the morphology of bare $\mathrm{ZnO}$. The modification at the surface of $\mathrm{ZnO}$ from hexagonal to pointed tips is due to the presence of $\mathrm{SiO}_{2}$ where it attaches to the nonpolar facets of $\mathrm{ZnO}$ which hinders the formation of hexagonal structure at its metastable facet. To maintain a much stable structure, the polar facets of $\mathrm{ZnO}$ may undergo surface reconstruction during the chemical deposition process resulting in the pointed tips of $\mathrm{ZnO}$ rods. Using low $\mathrm{OH}^{-}$ion concentration enables the growth of the mostly $c$-axis oriented $\mathrm{ZnO}-\mathrm{SiO}_{2}$ rods. This 


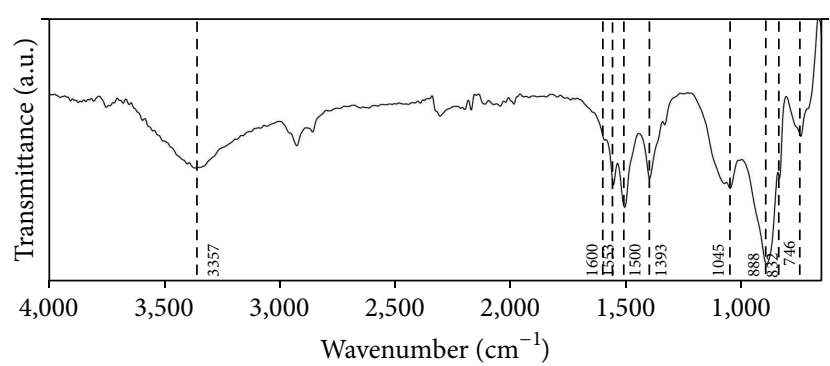

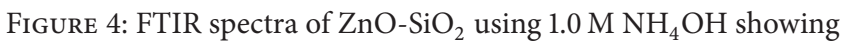
the functional groups of silica and $\mathrm{ZnO}$.

growth habit is due to the higher growth rate along the (0001) plane compared to other growth faces of $\mathrm{ZnO}$.

To confirm $\mathrm{ZnO}-\mathrm{SiO}_{2}$ formation, the infrared spectrum of $\mathrm{ZnO}_{-} \mathrm{SiO}_{2}$ using $1.0 \mathrm{M} \mathrm{NH}_{4} \mathrm{OH}$ is shown in Figure 4 . Characteristic peak at $746 \mathrm{~cm}^{-1}$ indicates the presence of $\mathrm{ZnO}$ [22]. The peaks at $832 \mathrm{~cm}^{-1}$ and $888 \mathrm{~cm}^{-1}$ are for the $\mathrm{Si}-\mathrm{O}-\mathrm{Si}$ asymmetric stretching vibrations while peak at $1063 \mathrm{~cm}^{-1}$ is for the Si-O-Si symmetric stretching. Peaks observed at $1500 \mathrm{~cm}^{-1}$ and $1553 \mathrm{~cm}^{-1}$ are for the $\mathrm{Si}-\mathrm{OH}$ stretching vibration and the peak at $1393 \mathrm{~cm}^{-1}$ is for the $\mathrm{Si}-\mathrm{O}-\mathrm{Si}$ bending. All of these characteristic peaks indicate the presence of the functional groups of amorphous silica from RHA. Furthermore, peak at $1600 \mathrm{~cm}^{-1}$ and a broad absorption band situated at $3000 \mathrm{~cm}^{-1}$ to $3600 \mathrm{~cm}^{-1}$ are attributed to the $\mathrm{O}-\mathrm{H}$ bending and $\mathrm{O}-\mathrm{H}$ stretching vibrations of $\mathrm{ZnO}-\mathrm{SiO}_{2}$, respectively, which reveals the presence of physically adsorbed water. Moreover, the peak at $1045 \mathrm{~cm}^{-1}$ is assigned for the $\mathrm{Si}-\mathrm{O}-\mathrm{Zn}$ stretching which confirms the formation of $\mathrm{ZnO}-\mathrm{SiO}_{2}$ [24, 25].

4.2. Characteristics of $\mathrm{ZnO}-\mathrm{SiO}_{2}$ Using Higher $\mathrm{NH}_{4} \mathrm{OH}$ Concentration. Increasing the ammonium hydroxide concentration resulted into much larger diameter but shorter rods. Flower-like formation and apparent change from pointed tips to hemispherical tips on the surface of the structures were observed as shown in Figure 5 for $\mathrm{ZnO}-\mathrm{SiO}_{2}$ deposited on glass substrate using $2.0 \mathrm{M} \mathrm{NH}_{4} \mathrm{OH}$. On the other hand, Figure 6 shows the micrographs of $\mathrm{ZnO}-\mathrm{SiO}_{2}$ using $3.0 \mathrm{M}$ $\mathrm{NH}_{4} \mathrm{OH}$ where much shorter $(\sim 0.850 \mu \mathrm{m})$ rods were present together with flake-like structures. The formation of flowerlike structures using high $\mathrm{NH}_{4} \mathrm{OH}$ concentration was due to the sufficient amount of $\mathrm{OH}^{-}$which was necessary for the nucleation and subsequently growth of anisotropic $\mathrm{ZnO}$ $\mathrm{SiO}_{2}$. The amorphous silica added to the ammonium-zincate bath solution causes the formation of hemispherical tips of the flower-like structures and is also the reason for having shorter and thicker rods. It is believed that, in higher $\mathrm{OH}^{-}$ ion concentration, the $\mathrm{SiO}_{2}$ capped the surface of $\mathrm{ZnO}$ rods leading to the formation of these hemispherical tips. This is due to enough $\mathrm{OH}^{-}$ions that interact with the silanol group of silica in the solution. The notable flakes observed in Figure 6 (encircled) are associated with the excess $\mathrm{OH}^{-}$ions and may form $\mathrm{Zn}$ complexes.

Figure 7 shows the infrared spectra of the chemically deposited $\mathrm{ZnO}-\mathrm{SiO}_{2}$ nanostructures prepared using high
$\mathrm{OH}^{-}$ion concentration together with the spectra of $\mathrm{ZnO}$ $\mathrm{SiO}_{2}$ prepared using $1.0 \mathrm{M} \mathrm{NH} \mathrm{NH}_{4} \mathrm{OH}$ for comparison. It was observed that intensity of the peaks at $1500 \mathrm{~cm}^{-1}$ and $1553 \mathrm{~cm}^{-1}$ attributed to the $\mathrm{Si}-\mathrm{OH}$ (silanol) stretches of silica decreases while peak at 1045-1050 associated with the Si$\mathrm{O}-\mathrm{Zn}$ band has a more pronounced intensity as $\mathrm{OH}^{-}$ion concentration is increased. This observation might suggest that the silanol group interacts with the $\mathrm{OH}^{-}$ions in the solution and that prolonged stirring resulted in the surface capping of $\mathrm{SiO}_{2}$ to $\mathrm{ZnO}$ resulting in the formation of flowerlike $\mathrm{ZnO}-\mathrm{SiO}_{2}$ with hemispherical tips.

The $\mathrm{X}$-ray diffraction diagram of the bare $\mathrm{ZnO}$ and amorphous $\mathrm{SiO}_{2}$ and the chemically deposited $\mathrm{ZnO}-\mathrm{SiO}_{2}$ nanostructures at varying $\mathrm{OH}^{-}$ion concentration are presented in Figures 8 and 9, respectively. A broad peak is observed centered at $21.6^{\circ}(2 \theta)$ which is attributed to the amorphous nature of $\mathrm{SiO}_{2}$ [26] while the diffractogram of bare $\mathrm{ZnO}$ showed the (100), (002), and (101) reflections indicating the formation of $\mathrm{ZnO}$. Presence of sulfides and hydroxides of zinc was also observed which is due to the precursors used as depicted in Figure 8. Figure 9, on the other hand, shows the diffractogram of the prepared $\mathrm{ZnO}-\mathrm{SiO}_{2}$ samples. Phase analysis revealed that the peaks correspond to wurtzite structure of $\mathrm{ZnO}$ as indexed to PDF 36-1451. The broad hump observed at $15-30^{\circ}(2 \theta)$ was associated to the amorphous silica added in the ammonium-zincate bath for the synthesis of $\mathrm{ZnO}-\mathrm{SiO}_{2}$; the same diffractogram was observed as in the work of [27]. Presence of hydroxide of zinc was also observed.

4.3. Proposed Mechanism for the Growth of $\mathrm{ZnO}-\mathrm{SiO}_{2}$. Following the chemistry of solution as previously discussed, the dropwise addition of $\mathrm{NH}_{4} \mathrm{OH}$ to aqueous solution of $\mathrm{ZnSO}_{4}$ produces $\mathrm{Zn}(\mathrm{OH})_{2}$ precipitate. For $\mathrm{ZnO}-\mathrm{SiO}_{2}$ prepared using $1.0 \mathrm{M} \mathrm{NH}_{4} \mathrm{OH}$, the $\mathrm{Zn}(\mathrm{OH})_{2}$ produces $\mathrm{Zn}^{2+}$ and $\mathrm{OH}^{-}$ions upon dissociation and induces the formation of $\mathrm{ZnO}$ nuclei. Based on the growth habit of $\mathrm{ZnO}$, using low initial $\mathrm{OH}^{-}$ ion concentration $(1.0 \mathrm{M})$ resulted in a slow rate of $\mathrm{ZnO}$ nuclei formation leading to the creation of flat end-rods with hexagonal shape as observed in Figure 1. This can be explained by the high growth rate along the (0001) plane of $\mathrm{ZnO}$ compared to the other growth faces resulting in a rod-like structure. Upon addition of amorphous silica to the solution, the silanol functional group of silica attaches to the nonpolar facets of $\mathrm{ZnO}$ and, to maintain a stable structure, the metastable polar facet of $\mathrm{ZnO}$ exhibits surface reconstruction resulting in the pointed tips of $\mathrm{ZnO}-\mathrm{SiO}_{2}$ rods.

However, using high initial $\mathrm{OH}^{-}$ion concentrations $(2.0 \mathrm{M}$ and $3.0 \mathrm{M})$ resulted in the flower-like formation of $\mathrm{ZnO}-\mathrm{SiO}_{2}$ with hemispherical tips. Based on the micrographs, hydroxide cluster formation might be favourable for the growth of flower-like structures. Since there are sufficient $\mathrm{OH}^{-}$ions, more $\mathrm{Zn}(\mathrm{OH})_{2}$ clusters were formed and subsequently adhere on the glass substrates which serve as seed nuclei while some may dissociate to $\mathrm{Zn}^{2+}$ and $\mathrm{OH}^{-}$ ions. Further addition of $\mathrm{NH}_{4} \mathrm{OH}$ triggers more formation of $\mathrm{Zn}(\mathrm{OH})_{2}$ which tends to continuously produce free $\mathrm{Zn}^{2+}$ and $\mathrm{OH}^{-}$ions and starts to form $\mathrm{ZnO}$ rods on the $\mathrm{Zn}(\mathrm{OH})_{2}$ 


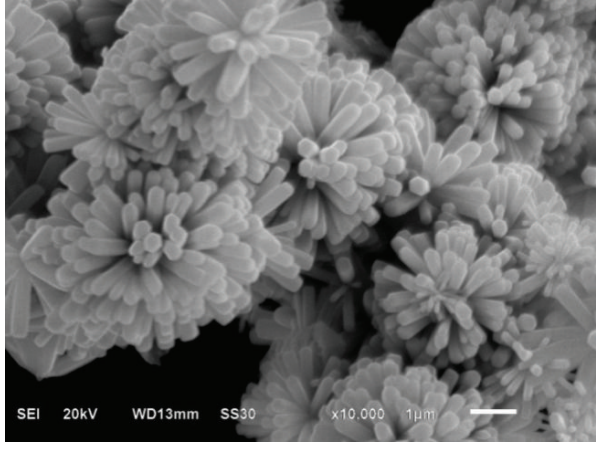

(a)

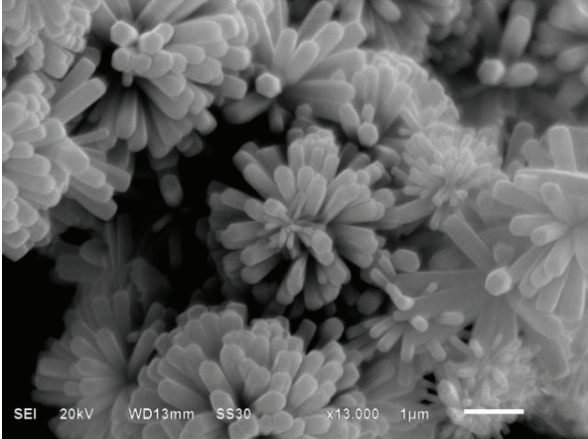

(b)

FIgURE 5: Micrograph of $\mathrm{ZnO}-\mathrm{SiO}_{2}$ using $2.0 \mathrm{M} \mathrm{NH}_{4} \mathrm{OH}$ showing flower-like $\mathrm{ZnO}-\mathrm{SiO}_{2}$ nanostructures having hemispherical tips. At (a) 10,000x magnification and (b) 13,000x magnification.

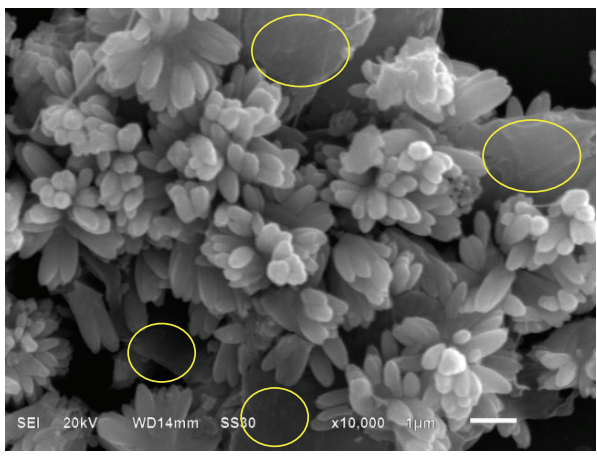

(a)

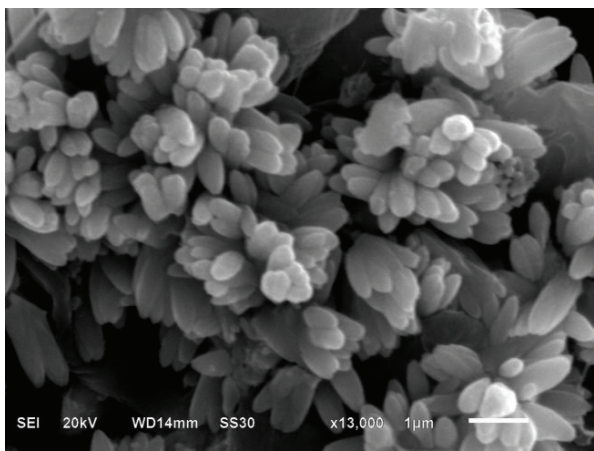

(b)

Figure 6: Micrograph of $\mathrm{ZnO}-\mathrm{SiO}_{2}$ using 3.0 M NH $\mathrm{N}_{4} \mathrm{OH}$ showing flower-like $\mathrm{ZnO}-\mathrm{SiO}_{2}$ nanostructures having shorter rods and more pronounced hemispherical tips. At (a) 10,000x magnification and (b) 13,000x magnification. Encircled are the flake-like structures.

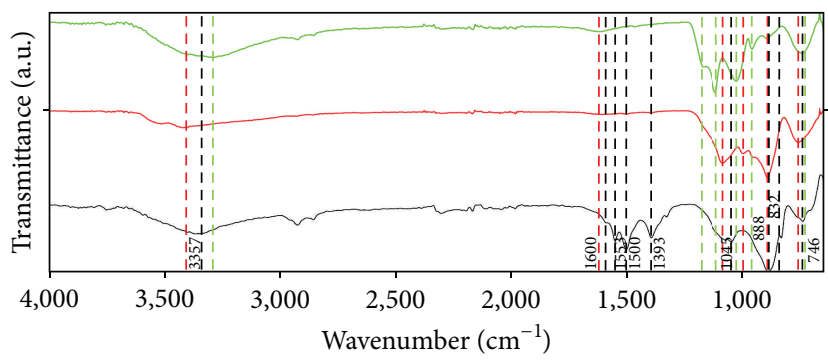

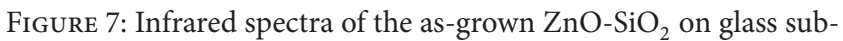
strate using $1.0 \mathrm{M}$ (black), $2.0 \mathrm{M}$ (red), and 3.0 M (green) $\mathrm{NH}_{4} \mathrm{OH}$.

seed nuclei. When amorphous silica was added, its silanol group attaches to the free $\mathrm{OH}^{-}$ions competing against the $\mathrm{Zn}^{2+}$ ions leaving more $\mathrm{Zn}^{2+}$ resulting in the formation of thicker and shorter $\mathrm{ZnO}-\mathrm{SiO}_{2}$ rods. Excess $\mathrm{OH}^{-}$ions, especially using 3.0 $\mathrm{M} \mathrm{NH}_{4} \mathrm{OH}$, lead to the formation of zinc complexes as evidently suggested by the flake-like structures. As deposition time is prolonged, $\mathrm{ZnO}-\mathrm{SiO}_{2}$ structures were slowly deposited on the substrate having already seed nuclei and, consequently, the neighbouring $\mathrm{ZnO}$ from the solution adheres on the seed nuclei that were already deposited on the

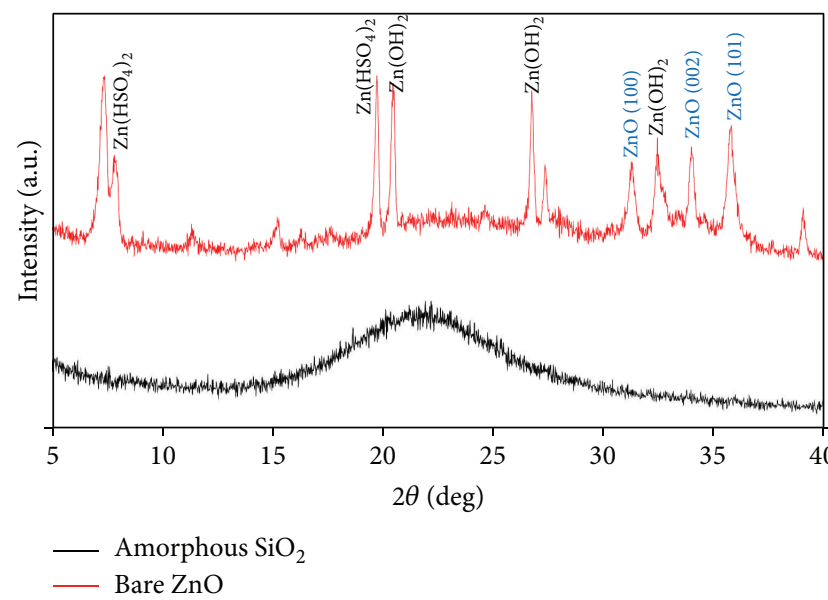

FIgURE 8: X-ray diffraction plot of amorphous $\mathrm{SiO}_{2}$ used in the study.

substrate and forms the flower-like structure. The formation of hemispherical tips is believed to be due to enough $\mathrm{OH}^{-}$ ions present in the solution that attaches to the silanol group (Si-OH) of silica and then subsequently caps the surface of $\mathrm{ZnO}$ rods resulting also in a much bigger but shorter rod. 


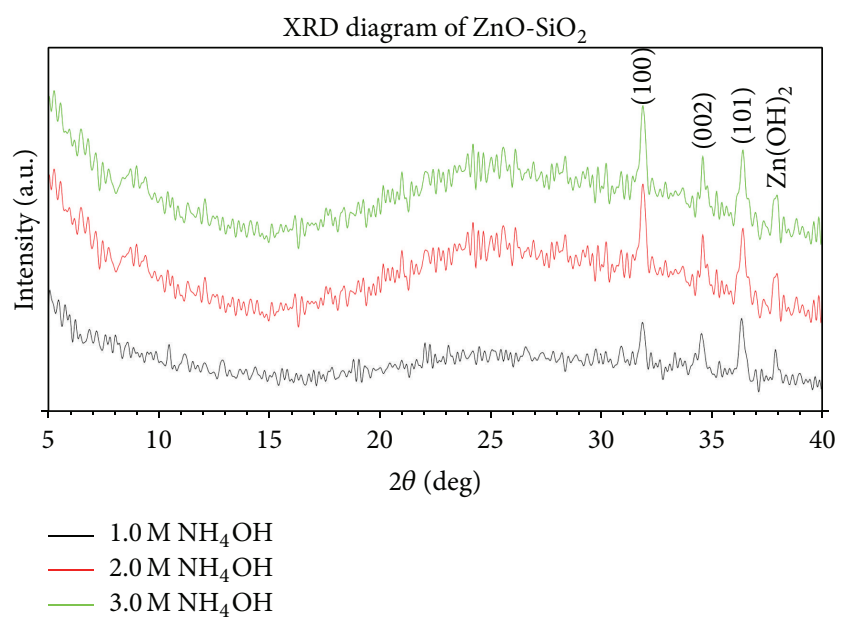

Figure 9: X-ray diffraction plot of the as-grown $\mathrm{ZnO}-\mathrm{SiO}_{2}$ on glass substrate using 1.0 M (black), 2.0 M (red), and 3.0 M (green) $\mathrm{NH}_{4} \mathrm{OH}$.

\section{Conclusion}

In conclusion, the control of the morphology of $\mathrm{ZnO}-\mathrm{SiO}_{2}$ was presented by changing initial $\mathrm{OH}^{-}$ion concentration. For a better understanding of the growth of $\mathrm{ZnO}-\mathrm{SiO}_{2}$, we demonstrated first the effect of $\mathrm{SiO}_{2}$ on the morphology of $\mathrm{ZnO}$ followed by the influence of varying $\mathrm{OH}^{-}$ion concentration on its size and shape. It was found that bare $\mathrm{ZnO}$ rods exhibit hexagonal morphology having a c-axis preferred growth direction. Addition of amorphous silica to the ammonium-zincate bath for $\mathrm{ZnO}-\mathrm{SiO}_{2}$ synthesis resulted in a remarkable change of morphology from hexagonal to "pointed tip" rods. Increasing initial $\mathrm{OH}^{-}$ion concentration produces "flower-like" structure having hemispherical top surface but shorter rods due to surface capping of silica to $\mathrm{ZnO}$. Infrared spectroscopic study confirms the formation of $\mathrm{ZnO}-\mathrm{SiO}_{2}$ from the functional groups present. Phase analysis by XRD suggested a wurtzite crystal structure of $\mathrm{ZnO}-\mathrm{SiO}_{2}$ was developed. Preliminary studies on the gas sensing capability and testing of the optical and electrical properties for solar cell application of the produced $\mathrm{ZnO}$ $\mathrm{SiO}_{2}$ are currently being conducted.

\section{Conflict of Interests}

The authors declare that there is no conflict of interests regarding the publication of this paper.

\section{Acknowledgment}

The authors would like to thank the Commission on Higher Education-Philippine Higher Education Research Network (CHED-PHERNet) through the Office of the Vice Chancellor for Research and Extension of MSU-IIT for the financial support of this research study.

\section{References}

[1] G. Jia, Y. Wang, and J. Yao, "Fabrication and optical properties of well-aligned $\mathrm{ZnO}$ nanorods on sapphire prepared by chemical bath deposition," Digest Journal of Nanomaterials and Biostructures, vol. 7, no. 1, pp. 261-267, 2012.

[2] C. Liu, L. Zheng, Z. Gao, Y. Gan, J. Zhang, and C. Li, "Effects of annealing conditions on $\mathrm{ZnO}$ buffer layer for inverted polymer solar cells," Optics and Photonics Journal, vol. 3, no. 2, pp. 222226, 2013.

[3] N. W. Emanetoglu, J. Zhu, Y. Chen, J. Zhong, Y. Chen, and Y. Lu, "Surface acoustic wave ultraviolet photodetectors using epitaxial $\mathrm{ZnO}$ multilayers grown on r-plane sapphire," Applied Physics Letters, vol. 85, no. 17, pp. 3702-3704, 2004.

[4] M. Suchea, S. Christoulakis, K. Moschovis, N. Katsarakis, and G. Kiriakidis, "ZnO transparent thin films for gas sensor applications," Thin Solid Films, vol. 515, no. 2, pp. 551-554, 2006.

[5] A. R. Kim, J.-Y. Lee, B. R. Jang, H. S. Kim, N. W. Jang, and J. Y. Lee, "Effect of $\mathrm{Zn}^{2+}$ source concentration on hydrothermally grown ZnO nanorods," Journal of Nanoscience and Nanotechnology, vol. 11, no. 7, pp. 6395-6399, 2011.

[6] M. A. Moghri Moazzen, S. M. Borghei, and F. Taleshi, "Change in the morphology of $\mathrm{ZnO}$ nanoparticles upon changing the reactant concentration," Applied Nanoscience, vol. 3, no. 4, pp. 295-302, 2013

[7] A. Laurentowska and T. Jesionowski, " $\mathrm{ZnO}-\mathrm{SiO}_{2}$ oxide composites synthesis during precipitation from emulsion system," Physicochemical Problems of Mineral Processing, vol. 48, no. 1, pp. 63-76, 2012.

[8] J. Sójka-Ledakowicz, J. Olczyk, A. Walawska, A. Laurentowska, A. Kolodziejczak-Radzimska, and T. Jesionowski, "Modification of textile products with nanosized zinc oxide and $\mathrm{ZnO}$ $\mathrm{SiO}_{2}$ oxide composite," Przemysl Chemiczny, vol. 89, no. 12, pp. 1648-1652, 2010.

[9] H. Barani, "Preparation of antibacterial coating based on in situ synthesis of $\mathrm{ZnO} / \mathrm{SiO}_{2}$ hybrid nanocomposite on cotton fabric," Applied Surface Science, vol. 320, pp. 429-434, 2014.

[10] M. Abdullah, S. Shibamoto, and K. Okuyama, "Synthesis of $\mathrm{ZnO} / \mathrm{SiO}_{2}$ nanocomposites emitting specific luminescence colors," Optical Materials, vol. 26, no. 1, pp. 95-100, 2004.

[11] N. Hagura, T. Takeuchi, S. Takayama, F. Iskandar, and K. Okuyama, "Enhanced photoluminescence of $\mathrm{ZnO}-\mathrm{SiO}_{2}$ nanocomposite particles and the analyses of structure and composition," Journal of Luminescence, vol. 131, no. 1, pp. 138146, 2011.

[12] J. Zhai, X. Tao, Y. Pu, X.-F. Zeng, and J.-F. Chen, "Core/shell structured $\mathrm{ZnO} / \mathrm{SiO}_{2}$ nanoparticles: preparation, characterization and photocatalytic property," Applied Surface Science, vol. 257, no. 2, pp. 393-397, 2010.

[13] Y.-L. Tang, Z.-J. Li, J.-Y. Ma, Y.-G. Guo, Y.-Q. Fu, and X.-T. Zu, "Ammonia gas sensors based on $\mathrm{ZnO} / \mathrm{SiO}_{2}$ bi-layer nanofilms on ST-cut quartz surface acoustic wave devices," Sensors and Actuators B: Chemical, vol. 201, pp. 114-121, 2014.

[14] Y. Sun, G. M. Fuge, and M. N. R. Ashfold, "Growth of aligned $\mathrm{ZnO}$ nanorod arrays by catalyst-free pulsed laser deposition methods," Chemical Physics Letters, vol. 396, no. 1-3, pp. 21-26, 2004.

[15] J.-J. Wu and S.-C. Liu, "Low-temperature growth of well-aligned $\mathrm{ZnO}$ nanorods by chemical vapor deposition," Advanced Materials, vol. 14, no. 3, pp. 215-218, 2002.

[16] W. I. Park, D. H. Kim, S.-W. Jung, and G.-C. Yi, "Metalorganic vapor-phase epitaxial growth of vertically well-aligned $\mathrm{ZnO}$ 
nanorods," Applied Physics Letters, vol. 80, no. 22, pp. 42324234, 2002.

[17] J.-S. Lee, K. Park, M.-I. Kang et al., " ZnO nanomaterials synthesized from thermal evaporation of ball-milled $\mathrm{ZnO}$ powders," Journal of Crystal Growth, vol. 254, no. 3-4, pp. 423-431, 2003.

[18] Q. X. Zhao, P. Klason, and M. Willander, "Growth of $\mathrm{ZnO}$ nanostructures by vapor-liquid-solid method," Applied Physics A, vol. 88, no. 1, pp. 27-30, 2007.

[19] M. H. Huang, Y. Wu, H. Feick, N. Tran, E. Weber, and P. Yang, "Catalytic growth of zinc oxide nanowires by vapor transport," Advanced Materials, vol. 13, no. 2, pp. 113-116, 2001.

[20] A. D. M. V. Peguit, R. T. Candidato Jr., R. M. Vequizo et al., "Controlling the growth of $\mathrm{ZnO}-\mathrm{SiO}_{2}$ nanostructures using Ptcoated Si substrate," Applied Mechanics and Materials, vol. 548549, pp. 354-357, 2014.

[21] E. Pantohan, R. Candidato, and R. Vequizo, "Surface modification of nanostructured hexagonal $\mathrm{ZnO}$ powder using amorphous silica powder via low temperature sol-gel process," Journal of Applied Science and Agriculture, vol. 9, no. 11, pp. 389394, 2014.

[22] R. N. Gayen, K. Sarkar, S. Hussain, R. Bhar, and A. K. Pal, “ZnO films prepared by modified sol-gel technique," Indian Journal of Pure and Applied Physics, vol. 49, no. 7, pp. 470-477, 2011.

[23] X. Ying-Mei, Q. Ji, H. De-Min et al., "Preparation of amorphous silica from oil shale residue and surface modification by silane coupling agent," Oil Shale, vol. 27, no. 1, pp. 37-46, 2010.

[24] K. T. Simfroso, A. C. Alguno, F. R. Bagsican et al., "Growth mechanism of chemically prepared $\mathrm{ZnO}-\mathrm{SiO}_{2}$ nanostructures grown on glass and silicon substrates," IOP Conference Series: Materials Science and Engineering, vol. 79, Article ID 012031, 6 pages, 2015.

[25] A. D. M. V. Peguit, R. T. Candidato Jr., F. R. Bagsican et al., "Growth of chemically deposited $\mathrm{ZnO}$ and $\mathrm{ZnO}-\mathrm{SiO}_{2}$ on $\mathrm{Pt}$ buffered Si substrate," IOP Conference Series: Materials Science and Engineering, vol. 79, Article ID 012026, 6 pages, 2015.

[26] S. Musić, N. Filipović-Vinceković, and L. Sekovanić, "Precipitation of amorphous $\mathrm{SiO}_{2}$ particles and their properties," Brazilian Journal of Chemical Engineering, vol. 28, no. 1, pp. 8994, 2011.

[27] K. S. Babu, A. R. Reddy, and K. V. Reddy, "Controlling the size and optical properties of $\mathrm{ZnO}$ nanoparticles by capping with $\mathrm{SiO}_{2}$," Materials Research Bulletin, vol. 49, no. 1, pp. 537-543, 2014. 

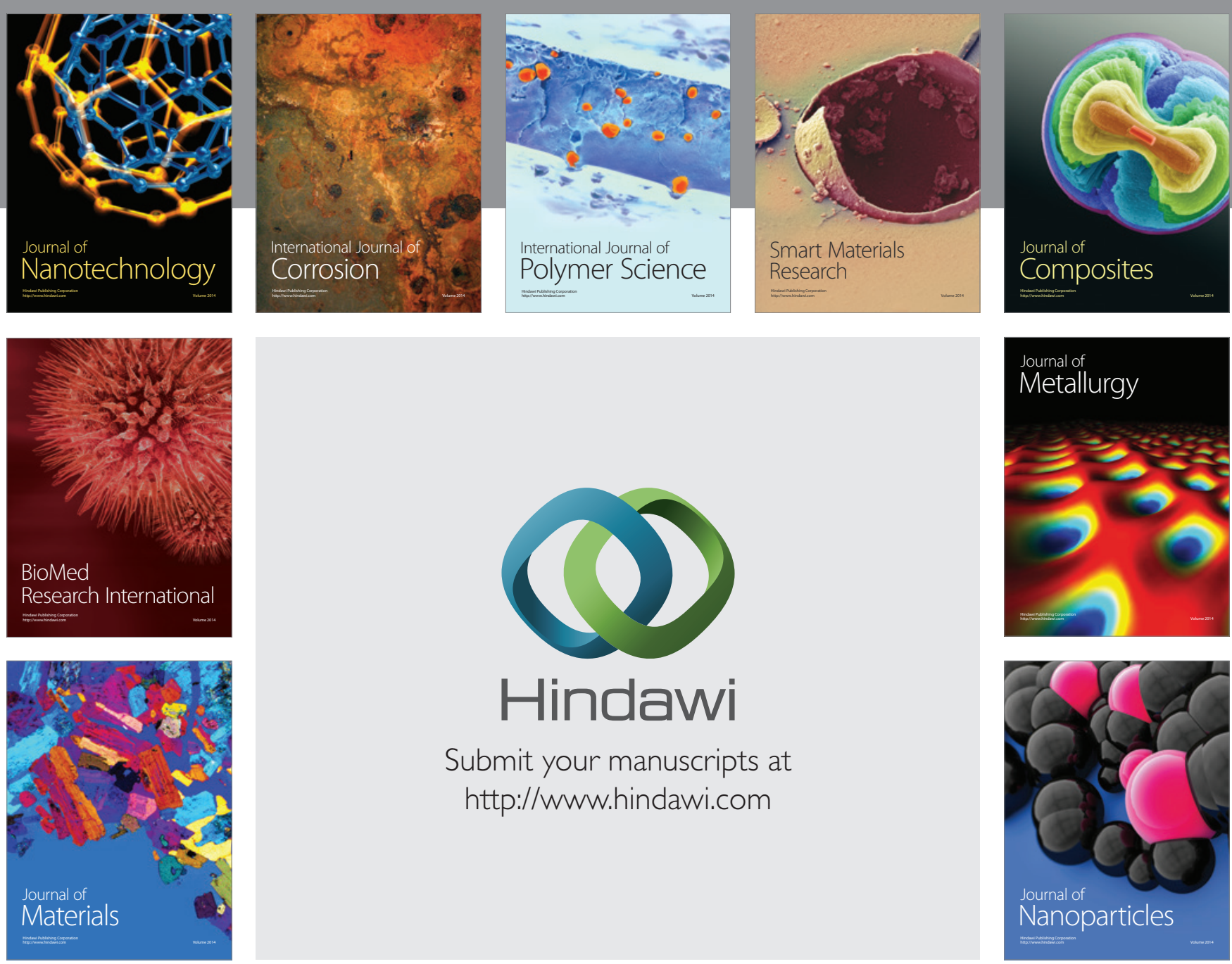

Submit your manuscripts at http://www.hindawi.com
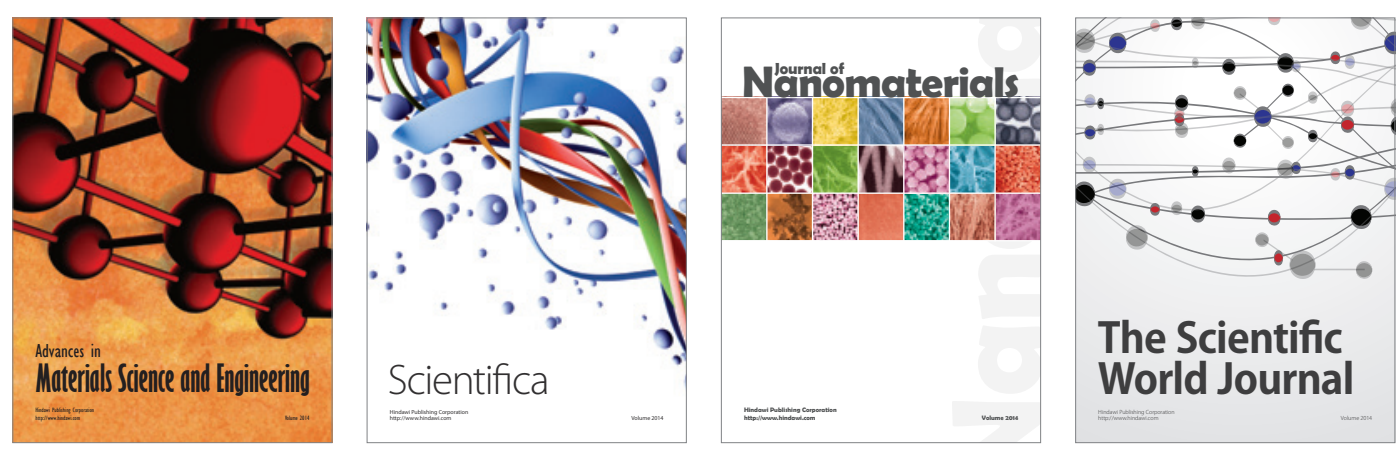

\section{The Scientific World Journal}
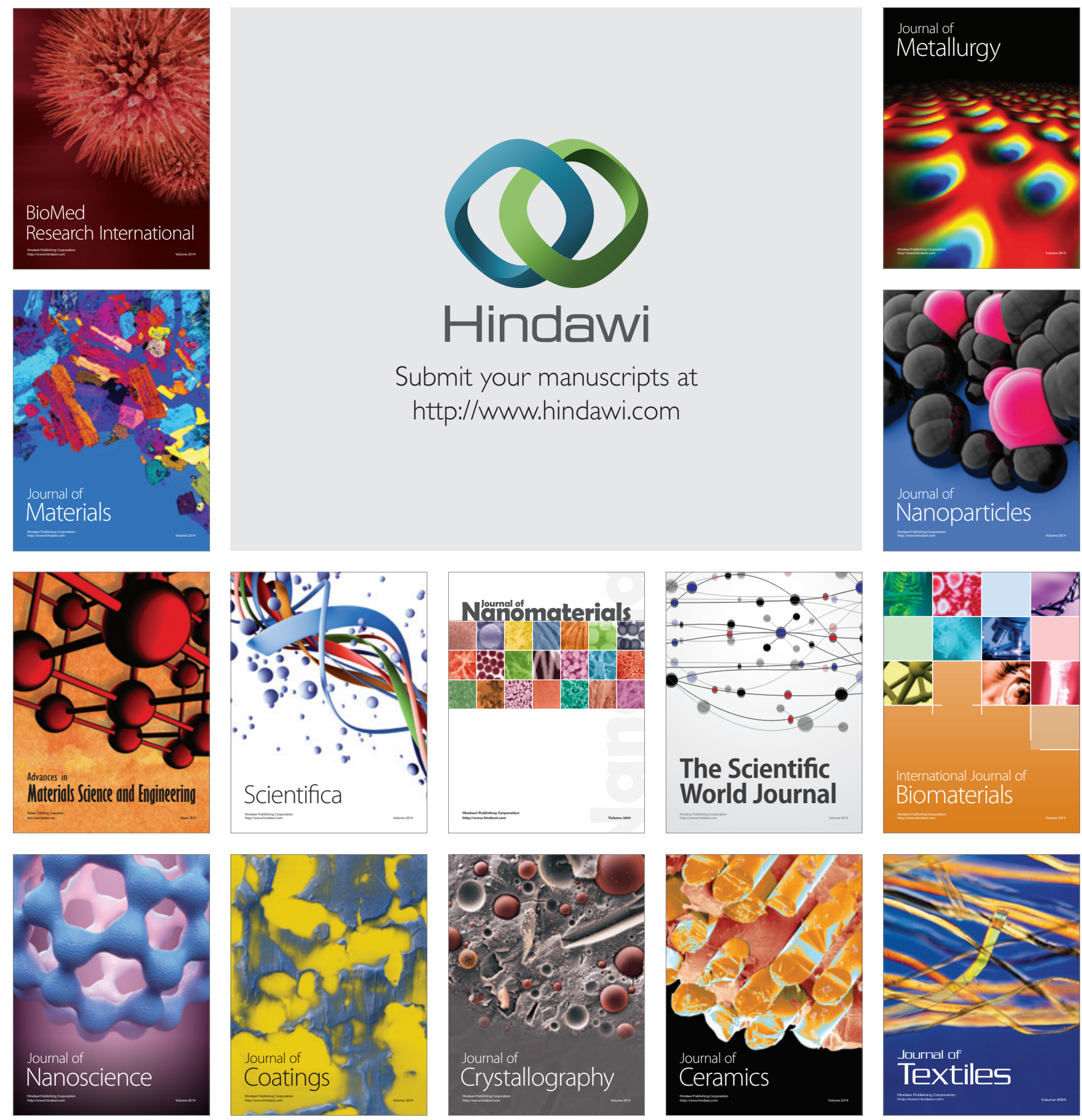